\title{
Study of the sensitivity of certain bacteria -pathogenic human health- to atlas cedar essential oils and antibiotics
}

\author{
Rabab Ez-Zriouli ${ }^{1}$, Houda El Yacoubi ${ }^{1}$, And Atmane Rochdi ${ }^{1}$ \\ ${ }^{1}$ Laboratory of natural resources and sustainable development, Faculty of Sciences, University \\ Ibn Tofail, Kenitra 14000, Morocco.
}

\begin{abstract}
The spread of microbial resistance around the world is one of the most serious threats to public health. Every year one to three antibiotics are released to the market, as each antibiotic has a limited effective lifespan after which microorganisms develop resistance. The need to identify new natural antimicrobial agents is an important research goal at the global level. The use of volatile plant extracts as antimicrobial agents represents a low risk for the development of resistance by microorganisms because these products are made up of several phytocompounds from different groups which work in synergy. The objective of this work is to test, in vitro, the antimicrobial activity of the essential oil of cedrus atlantica against six bacterial strains; Salmonella sp, Staphylococcus aureus, Escherichia coli, Klebsiella pneumoniae, Pseudomonas aeruginosa and streptococcus sp. And three strains of yeast; Candida Tropicalis, Candida Albicans, Saccharomyces Cerevisiae. With the aim of researching new effective antibacterial substance with a broad spectrum of action. The results of the quantitative analysis showed a richness in certain compounds identified by gas chromatography coupled with mass spectrometry; $\beta$-Himachalene, $\alpha$-Himachalene, himachalene oxide and Limonene. The essential oil to show a significant antibacterial effect compared to the synthetic antibiotics tested Piperacillin $30 \mu \mathrm{g}$ (PRL30) and Ampicillin $10 \mu \mathrm{g}$ (AMP 10). Key words: Cedrus atlantica, essential oil, antimicrobial activity, GC / MS, antibiotics
\end{abstract}

\section{Introduction}

The fight against microbial attacks is based primarily on the use of antibiotics. However, for several years, the selection of multidrug-resistant strains has been observed in human medicine, for which the abusive therapeutic use of antibiotics is largely responsible. In order to preserve human health, the discovery of new molecules has become an absolute necessity[1]. The fields of investigation are vast but the exploration of natural resources and especially plants which have always been a source of inspiration for new drugs appears to be the most promising because these constitute the largest reserve of active substances [2], [3].

Among the forest species of Morocco, the Atlas cedar has always been considered as the emblematic noble species of the Atlas Mountains (130,000 ha) and the Rif (15,000 ha), appreciated for its technological, ecological and biogeographical values[4].

The cedar is a coniferous tree, which can reach a height of 30 to $40 \mathrm{~m}$, of the Panacea family [5]. It is highly sought after for its many uses (sawing, charcoal, etc.).[6] The essential oils derived from $C$. atlantica are used in various products, such as medicines and perfumes[7].
This work is devoted to the study of the chemical composition of the essential oil of cedrus atlantica and its antimicrobial power on pathogenic microorganism.

\section{Material and method}

\subsection{Plant material and analysis by GC/MS}

Before extraction, the aerial parts of cedrus atlantica were dried in the shade in a ventilated place. The EO is extracted by hydrodistillation using a Clevenger type apparatus [8]. the extraction lasted 3 hours by placing $250 \mathrm{~g}$ of the leaves of the plant in a flask with distilled water. The oil obtained is then analyzed by gas chromatography coupled to a mass spectrum (GC / MS) of the (polarisQ) type, ion trap in electonic impact mode (EI) with ionization energy. from $70 \mathrm{ev}$. The column used is an apolar capillary column in silica of the type (Wcot Fused Silica), with a stationary phase (CPSIL5CB), $50 \mathrm{~m}$ in length, the temperature of the column

\footnotetext{
* Corresponding author: ezzrioulirabab01@gmail.com
} 
is programmed from 40 to $280^{\circ} \mathrm{C}$ at a rate of $3{ }^{\circ} \mathrm{C} /$ $\min$. The temperature of the injector is set at $240^{\circ} \mathrm{C}$ and that of the detector (ionization source) is $200^{\circ} \mathrm{C}$. The flow rate of the carrier gas (helium) is set at $1 \mathrm{ml} / \mathrm{min}$. The volume of the sample injected is $1 \mu \mathrm{l}$ of EO diluted in methanol $(1 \% \mathrm{v} / \mathrm{v})$

\subsection{Microorganism}

Bacterial Strains: Gram+ positif (Staphylococcus aureus, streptococcus sp), Gram- negatif (Escherichia coli, salmonella sp, Klebsiella pneumoniae, Pseudomonas Aeruginosa)

Yeasts: Candida Tropicalis, Candida Albicans, Saccharomyces Cerevisiae

Antibiotics: The antibiotics used are: Piperacillin (PRL 30), Ampicillin (AMP 10).

\subsection{Testing for antibacterial activity by the diffusion method}

From a microbial inoculum of $108 \mathrm{cfu} / \mathrm{mL}$, petri dishes containing Muller-Hinton solid culture medium for bacteria and Sabouraud for yeasts were inoculated by spreading. Then a sterile disc of Wattman paper $6 \mathrm{~mm}$ in diameter soaked in $15 \mu \mathrm{l}$ of the essential oil of cedrus atlantica is placed in the center of each dish on the surface of the agar medium. For the positive controls antibiotic discs were used; Piperacillin $30 \mu \mathrm{g}$ and Ampicillin $10 \mu \mathrm{g}$. once the dishes are prepared, they are incubated at $37^{\circ} \mathrm{C}$. for 24 hours for the bacteria and 48 hours at $30^{\circ} \mathrm{C}$. for the yeasts. The sensitivity of the strains was assessed by measuring the diameters of the zones of inhibition formed around the discs. Each test is repeated three times under the same experimental conditions to confirm the results [9].

\subsection{Antibacterial activity test by the solid medium dilution method}

The minimum inhibitory concentration (MIC) and the minimum bactericidal or fungicidal concentration (MBC / MFC) of the volatile extract is determined by the dilution method [10]. This technique consists of making successive dilutions of the essential oil in the culture medium. After solidification, the medium is inoculated with the strain and incubated according to the ideal conditions for each microorganism. The results give the MIC as the lowest concentration for which we do not observe growth with the naked eye.

\subsection{Statistical analysis}

The data obtained were analyzed using the Genstat software, a one-way variance (ANOVA) analysis was performed in addition to the comparison of means according to the Bonferroni test.

\section{Results and discussion}

\subsection{Chemical composition of the volatil extract}

the GC / MS analysis spectrum of the essential oil isolated from the leaves of cedrus atlantica by hydrodistillation is shown in figure 1. The essential compound of this oil, the retention times and the distribution air are summarized in Table 1. Eleven compounds have been identified, the major constituents of which are; $\beta$-Himachalene (54.21\%), $\gamma$-Himachalene) $15.54 \%)$, Himachalene oxide $(6.23 \%)$ and Limonene $(6.12 \%)$. Compared with the results reported in the literature, the compounds found in the essential oil of cedrus atlantica in high percentage in samples of plants from morocco are: $\alpha$-pinene $(14,85 \%)$, himachalene $(10.14 \%), \quad \beta$-himachalene $\quad(9,89 \%), \quad \sigma$-himachalene $(7,62 \%)$, and cis- $\alpha$-atlantone $(6,78 \%)$ [11].

others research al have shown that cedrus atlantica oil is rich in $\beta$-Himachalene with a content of about $31.24 \%$, followed by $\alpha$-himachalene $(15.63 \%)$ and $\gamma$ Himachalene (14.46\%) [12].

This difference in composition may be due to various factors such as geographic environment, harvest season, genotype, temperature and location of drying, and method of extraction.

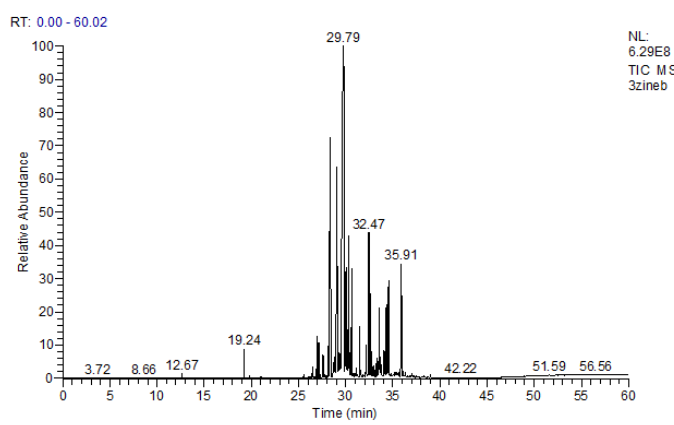

Fig. 1. GC / MS analysis chromatographic profile of essential oil of cedrus atlantica

Table 1. Chemical composition of Cerdus Atlantica essential oil by GC / MS

$\begin{array}{ccc}\text { Chemical Compounds } & \begin{array}{c}\text { Percentage } \\ (\%)\end{array} & \begin{array}{c}\text { Retention Time } \\ \text { (RT) } /(\min )\end{array}\end{array}$

$\begin{array}{ccc}\beta \text {-sinensal } & 0,01 & 3,72 \\ \text { Isoledene } & 0,04 & 8,66 \\ \text { Himachala-2,4-diene } & 0,1 & 12,67 \\ \text { Humulene } & 1,2 & 19,24 \\ \text { Himachalene } & 1.16 & 26.94 \\ \text { Isocaryophillene } & 0.91 & 27.16\end{array}$




\begin{tabular}{|c|c|c|}
\hline y -Himachalene & 15.54 & 28.4 \\
\hline$\beta$-Himachalene & 54.21 & 29.79 \\
\hline a-Pinene & 1.08 & 30.52 \\
\hline Cymene & 2.68 & 30.67 \\
\hline 3-Carene & 1.42 & 31.49 \\
\hline Himachalene oxide & 6.23 & 32.47 \\
\hline$\delta$-Cadinene & 3.24 & 32.65 \\
\hline Longifolene & 3.17 & 33.61 \\
\hline Limonene & 6.12 & 34.55 \\
\hline
\end{tabular}

\subsection{Antibacterial activity}

The results of the antimicrobial activity are shown in Tables 2 and 3 the analysis of variance to show that the differences between the strains are not significant $(\mathrm{P}>$ $0.05)$ for the essential oil and very highly significant for the Ampicillin $(\mathrm{P}<0.001)$. The comparison of the means, the Bonferroni test to show that there is a variability between the classes i.e. the essential oil and the Ampicillin did not react in the same way vis-à-vis the strains tested. Regarding the antibiotic Piperacillin, it has not shown any effect on all microorganisms. Usually the yeasts appeared very sensitive in the presence of the essential oil followed by Staphylococcus aureus, streptococcus $s p$ and salmonella $s p$

According to the method of dilution on a solid medium, the values of MIC and MBC / MFC of EO with respect to the microorganisms tested are grouped together in table 4. For yeasts, the strain most sensitive to the effect of the essential oil is $S$. Cerevisiae for which the MIC value of $0.5 \mu \mathrm{l} / \mathrm{ml}$ is the minimum EO concentration capable of inhibiting the growth of this strain, therefore the extract to exert a fungistatic effect on the yeast. In the case of bacteria, $S$. aureus to show a significant sensitivity to EO compared to other bacteria, in fact the $10 \mu \mathrm{l} / \mathrm{ml}$ concentration of the extract in the culture medium has a bactericidal power with respect to this strain. For the other strains, it is estimated that at higher concentrations, EO may give better results than those obtained in this study.

Some authors have advanced the resistance of Staphylococcus aureus compared to other essential oil strains of cedrus atlantica [13]. Others have proven that strains react differently depending on the composition of cedarwood oil, and the components of essential oils are classified according to their antimicrobial potency in the following descending order: Alcohol $>$ ketones $>$ Hydrocarbons [14], [15]. Usually the antimicrobial activity is due to the different chemical compounds present in this extract, including the major compounds and the synergistic effect of the minor compounds [16], [17]. These molecules have an important characteristic, namely hydrophobicity, which allows them to react with the membrane lipids of the bacterial cell and the mitochondria, disrupting their structures and making them more permeable. This promotes the escape of ions and the loss of cell content and ultimately cell death. [18], [19], [20].

In addition, the antimicrobial activities of extracts of aromatic and medicinal plants depend on various factors; solvent used for the extraction, conditions under which the plant grew, strains chosen and the method for determining antimicrobial activity ...[21].

\section{Conclusion}

The essential oil analyzed is characterized by a very diverse chemical composition. As the results obtained in microbiology during this research relate to the concentrations used, the results of our work constitute a first step in the search for alternative control treatments against bacterial and fungal diseases. This study will be complemented by further confirmations on other plant extracts and other strains.

Table 2. Analysis of variance

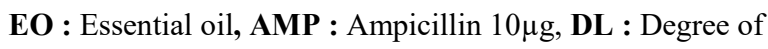

liberty, SS : Sum of the squares of the deviations, MS : Mean of the squares of the deviations, $\mathbf{P}$ : probability

\begin{tabular}{cccccc}
\hline \multicolumn{2}{c}{ source of variation } & DL & SS & MS & P \\
\hline \multirow{2}{*}{ EO } & Strains & 8 & 937,33 & 117,17 & $\mathbf{0 , 0 6 5}$ \\
& Residual & 16 & 781,11 & 48,82 & \\
\multirow{2}{*}{ AMP } & Strains & 5 & 444,4444 & 88,8889 & $<, 001$ \\
& Residual & 10 & 8,8889 & 0,3889 & \\
\hline
\end{tabular}

Table 3. Comparison of means ( Bonferroni Test)

AMP: Ampicillin $10 \mu \mathrm{g}$, PRL : Piperacillin $30 \mu \mathrm{g}, \quad$ NT : not

tested, $a$ and $b$ represent the classes generated by the comparison of Bonferroni means

means of the diameters of the inhibition zones $(\mathrm{mm})$

\begin{tabular}{cccc} 
Strains & EO & AMP 10 & PRL 30 \\
\hline C.Albicans & $20,33 \mathrm{a}$ & $\mathrm{NT}$ & $\mathrm{NT}$ \\
S. Cerevisiae & $20,33 \mathrm{a}$ & $\mathrm{NT}$ & $\mathrm{NT}$ \\
C.Tropicalis & $15,33 \mathrm{a}$ & $\mathrm{NT}$ & $\mathrm{NT}$ \\
S.Aureus & $14,67 \mathrm{a}$ & $13,333 \mathrm{a}$ & $0,000 \mathrm{a}$ \\
Strypto sp & $12,67 \mathrm{a}$ & $0,000 \mathrm{~b}$ & $0,000 \mathrm{a}$ \\
Salmonella sp & $10,33 \mathrm{a}$ & $0,000 \mathrm{~b}$ & $0,000 \mathrm{a}$ \\
E.Coli & $9,67 \mathrm{a}$ & $0,000 \mathrm{~b}$ & $0,000 \mathrm{a}$ \\
K.Pneumoniae & $9,67 \mathrm{a}$ & $0,000 \mathrm{~b}$ & $0,000 \mathrm{a}$ \\
Ps. Aeruginosa & $0,00 \mathrm{a}$ & $0,000 \mathrm{~b}$ & $0,000 \mathrm{a}$
\end{tabular}


Table 4. The MIC and MBC/MFC of EO of cedrus atlantica against the microorganism

$\mathrm{Nd}$ : not determined

\begin{tabular}{ccc}
\hline Microorganism & \multicolumn{1}{c}{ Cedrus Atlantica essential oil $(\mu \mathrm{l} / \mathrm{ml})$} \\
\hline Bacterial strains & MIC & MBC/MFC \\
Salmonella sp & $\mathrm{Nd}$ & $\mathrm{Nd}$ \\
S.Aureus & 10 & 10 \\
E.Coli & $\mathrm{Nd}$ & $\mathrm{Nd}$ \\
K.Pneumoniae & $\mathrm{Nd}$ & $\mathrm{Nd}$ \\
Ps. Aeruginosa & $\mathrm{Nd}$ & $\mathrm{Nd}$ \\
Strypto sp & $>10$ & $>10$ \\
Yeasts & & \\
C.Tropicalis & $\mathrm{Nd}$ & $\mathrm{Nd}$ \\
C.Albicans & 10 & $\mathrm{Nd}$ \\
S. Cerevisiae & 0.5 & $\mathrm{Nd}$ \\
& & \\
\hline
\end{tabular}

\section{References}

1. Diallo, K. Et Al. Impact D'une Intervention Par Une Equipe Transversale D'infectiologie En Chirurgie Maxillo-Faciale. Médecine Mal. Infect. 50, S48-S49 (2020).

2. Khribch, J., Nassik, S., Houadfi, M. E., Zrira, S. \& Oukessou, M. Activité Antibactérienne De L'huile Essentielle D'origan Et Du Carvacrol Sur Des Souches D'escherichia Coli D'origine Aviaire. Rev. Marocaine Sci. Agron. Vét. 6, 300-307 (2018).

3. Ainane, A. Et Al. Chemical Composition And Antimicrobial Activity Of The Essential Oil Of Pistacia Lentiscus L. Phol - Pharmacol. 2, 518-526 (2021).

4. Laaribya, S. \& Alaoui, A. Modélisation Par L'entropie Maximale De L'habitat Potentiel Du Cèdre De L'atlas Au Maroc (Cedrus Atlantica Manetti). Rev. Nat. Technol. 10 (2021).

5. Jaouadi, I. Et Al. Wood Tar Essential Oil From Cedrus Atlantica Of Morocco (Middle Atlas) As A Green Corrosion Inhibitor For Mild Steel In $1 \mathrm{M}$ Hydrochloric Acid Solution. Int. J. Corros. Scale Inhib. 9, (2020).

6. Skanderi, I. \& Chouitah, O. Chemical Characterization And Antioxidant Activity Of Cedrus Atlantica Manetti Tar (Atlas Cedar Tar). Fr.-Ukr. J. Chem. 8, 244-255 (2020).

7. Bennouna, F., Lachkar, M., Abed, S. E. \& Koraichi, S. I. Cedrus Atlantica Essential Oil: Antimicrobial Activity And Effect On The Physicochemical Properties Of Cedar Wood Surface. Moroc. J. Biol. 12 (2019).
8. Clevenger, J. F. Apparatus For The Determination Of Volatile Oil. J. Am. Pharm. Assoc. 1912 17, 345-349 (1928).

9. Boukhalfoun, L., Kirouani, A., Behidj, N. \& Gana, S. Assessment Of Some Biological Activities of Eucalyptus Blakelyi Maiden Using The Essential Oil, Methanolic And Aqueous Extracts. J. Essent. Oil Bear. Plants $1-10$ (2020) Doi:10.1080/0972060x.2020.1752818.

10. Hajib, A. Et Al. Chemical Composition And Biological Activities Of Essential Oils From The Fruits Of Cuminum Cyminum L. And Ammodaucus Leucotrichus L. (Apiaceae). J. Essent. Oil Bear. Plants 23, 474-483 (2020).

11. Derwich, E., Benziane, Z. \& Boukir, A. Chemical Composition And In Vitro Antibacterial Activity Of The Essential Oil Of Cedrus Atlantica. Int. J. Agric. Biol. 12, 6 (2010).

12. Ainane, A. Et Al. Composition Chimique Et Activité Insecticide De Cinq Huiles Essentielles: Cedrus Atlantica, Citrus Limonum, Eucalyptus Globules, Rosmarinus Officinalis Et Syzygium Aromaticum. Colloq. Natl. Biosune'1 67-79 (2019).

13. Aberchane, M., Satrani, B., Fechtal, M. \& Chaouch, A. Effet De L'infection Du Bois De Cèdre De L'atlas Par Trametes Pini Et Ungulina Officinalis Sur La Composition Chimique Et L'activité Antibactérienne Et Antifongique Des Huiles Essentielles. Acta Bot. Gallica 150, 223-229 (2003).

14. Benouaklil, F., Hamaidi-Chergui, F.,

Hamaidi Mohand, S., \& Saidi, F.

Chemical Composition

And Antimicrobial

Properties Of Algerian C. Atlanticam.

Essential Oils. Revue Agrobiologia 7(1): 355-362(2017).

15. Satrani, B., Farah, A. \& Talbi, M. Effet De La Distillation Fractionnée Sur La Composition Chimique Et L'activité Antimicrobienne Des Huiles Essentielles Du Myrte (Myrtus Communis L.) Du Maroc. Acta Bot. Gallica 153, 235-242 (2006).

16. Uwineza M. S., El Yousfi, B. \& Lamiri, A. Antifungal Activities Of Essential Oils Of Mentha Pulegium, Eugenia Aromatica And Cedrus Atlantica On Fusarium Culmorum And Bipolaris Sorokiniana In Vitro. Rev Maro Protec Plants 12,19-32(2018).

17. Fidah, A. Et Al. Natural Durability Of Cedrus Atlantica Wood Related To The Bioactivity Of Its Essential Oil Against Wood Decaying Fungi. Maderas Cienc. Tecnol. 18, 567-576 (2016).

18. Ultee, A., Bennik, M. H. J. \& Moezelaar, R. The Phenolic Hydroxyl Group Of Carvacrol Is Essential For Action Against The Food-Borne 
Pathogen Bacillus Cereus. Appl. Environ. Microbiol. 68, 1561-1568 (2002).

19. Carson, C. F., Mee, B. J. \& Riley, T. V. Mechanism Of Action Of Melaleuca Alternifolia (Tea Tree) Oil On Staphylococcus Aureus Determined By Time-Kill, Lysis, Leakage, And Salt Tolerance Assays And Electron Microscopy. Antimicrob. Agents Chemother. 46, 1914-1920 (2002).

20. Lambert, R. J. W., Skandamis, P. N., Coote, P. J. \& Nychas, G.-J. E. A Study Of The Minimum Inhibitory Concentration And Mode Of Action Of Oregano Essential Oil, Thymol And Carvacrol. J. Appl. Microbiol. 91, 453462 (2001).

21. Jothiprakasam, V., Ramesh, S. \& Rajasekharan, S. K. Preliminary Phytochemical Screening And Antibacterial Activity Of Lawsonia Inermis Linn (Henna) Leaf Extracts Against Reference Bacterial Strains And Clinically Important Ampc BetaLactamases Producing Proteus Mirabilis. Ternational J. Pharm. Pharm. Sci. 5, 5 (2013). 